\title{
Eimeria phocae (Apicomplexa: Eimeriidae) in harbour seals Phoca vitulina from Sable Island, Canada
}

\author{
G. McClelland
}

Department of Fisheries and Oceans, Halifax Fisheries Research Laboratory, PO Box 550, Halifax, Nova Scotia, Canada B3J 2S7

\begin{abstract}
Eimeria phocae infections were detected in eight 5 to 10 mo old harbour seals Phoca vitulina housed in the Life Sciences Centre, Dalhousie University, Halifax. Nova Scotia, Canada. All seals occupying the facility had been captured on Sable Island, an emergent sand bar lying in the Northwest Atlantic $160 \mathrm{~km}$ east of mainland Nova Scotia. Oocysts sporulated in thin layer culture or faeces incubated in air but not when suspended in standing or aerated seawater. Sporulation time varied from $50 \mathrm{~h}$ at $20^{\circ} \mathrm{C}$ to $1300 \mathrm{~h}$ at $0.2^{\circ} \mathrm{C}$. Most infections were asymptomatic but clinical signs that included lethargy, loss of appetite and hemorrhagic diarrhea developed in 2 underweight males. Subsequent necropsy of one of these seals revealed endogenous stages of the parasite and associated pathology in the proximal $3 \mathrm{~m}$ of small intestine. Giant meronts $80-128 \times 64-85 \mu \mathrm{m}$ were found in colonies of 800 to 1200 , which formed macroscopic nodules $900-1520 \times 750-1050 \mu \mathrm{m}$ extending from submucosa to intestinal lumen. Macro- and microgamonts were confined to lamina propria of villi. Areas of intestine with high gamont densities were marked by haemorrhaging, polymorphonuclear leukocyte infiltration (mainly eosinophils), shortening and thickening of villi and necrosis and shedding of epithelium and lamina propria.
\end{abstract}

KEY WORDS: Apicomplexa $\cdot$ Coccidia $\cdot$ Eimeria phocae $\cdot$ Harbour seal $\cdot$ Phoca vitulina

\section{INTRODUCTION}

Hsu et al. (1974b) reported the first known cases of clinical coccidiosis in seals. Both cases, including one which was fatal, occurred in harbour seals Phoca vitulina captured near Portland, Maine (USA) and, at the time of onset of symptoms, housed in facilities at Johns Hopkins University, Baltimore, Maryland. Hsu et al. (1974a) subsequently described the oocysts and gamonts of the parasite, which they named Eimeria phocae. No new cases of phocine coccidiosis were documented for more than $15 \mathrm{yr}$. Moreover, for almost a decade, E. phocae remained the only eimeriid described from a marine mammal host, although other coccidians (Sarcocystis and Toxoplasma spp.) were reported in various pinnipeds and cetaceans (Howard et al. 1983, Dailey 1985, Lauckner 1985).

In a recent survey of Antarctic seals, Dróżdż (1987) described oocysts of Eimeria weddelli and Eimeria arc- towski from Weddell seals Leptonychotes weddelli, Isospora mirungae from elephant seals Mirunga leonina and 3 other coccidia morphotypes from Weddell and crab eater seals Lobodon carcinophagus. Oocysts of Eimeria spp. were also described from Amazonian manatee Trichechus inunquis (Lainson et al. 1983) and Florida manatee Trichechus manatus (Upton et al. 1989). More recently, fatal haemorrhagic enteritis associated with Eimeria sp. infection was reported in common (harbour) seal pups held in a seal sanctuary in Shetland, Scotland (Munro \& Synge 1991) and diagnosed in August 1992 in grey seals Halichoerus grypus housed in the Life Sciences Centre, Dalhousie University, Halifax, Nova Scotia (John Parsons, Biology Dept, Dalhousie University, pers. comm.).

The 1992 outbreak in captive grey seals was not the first occurrence of phocine coccidia in the Dalhousie Life Sciences Centre. Eimeria phocae were detected in harbour seals maintained in the same facility from 
September 1974 to April 1975 (McClelland 1980b). All seals occupying the Life Sciences Centre at the time had been captured on Sable Island, an emergent sand bar lying on the continental shelf $160 \mathrm{~km}$ east of mainland Nova Scotia (McClelland 1980a). Only one other coccidian, Sarcocystis sp. in the musculature of pilot whales Globiocephala melaena (Cowan 1966), has been reported in marine mammals from Canadian waters (Kennedy et al. 1989).

In an effort to identify, treat and prevent transmission of coccidia during the $1974-75$ outbreak at Dalhousie University, faecal oocyst counts, patency periods and sporulation time-temperature relationships were determined. Exogenous and endogenous stages, including the previously undescribed meronts, and the pathology associated with infection at the gross and histological levels were also studied. The results of these studies are reported here.

\section{MATERIALS AND METHODS}

Seal maintenance and facilities were described in an earlier study (McClelland 1980a). All seals were captured on Sable Island, an emergent sand bar lying in the Northwest Atlantic, approximately $160 \mathrm{~km}$ east of mainland Nova Scotia, Canada. Harbour seals Phoca vitulina included 12 pups collected when 3 to $8 \mathrm{wk}$ old in June and August 1974, a yearling captured in August 1974 and a 2 yr old taken as a pup in June 1972. Two 4 wk old grey seals Halichoerus grypus were also taken in early February 1975. Seals were housed in the $40 \mathrm{~m}^{3}$ outdoor tank and in the $940 \mathrm{~m}^{3}$ indoor tank in the Life Sciences Centre, Dalhousie University, Halifax, Nova Scotia. Both indoor and outdoor facilities were provided with a continuous flow of fresh prefiltered seawater at approximately $0.3 \mathrm{~m}^{3} \mathrm{~min}^{-1}$. Seals were fed a vitamin-supplemented diet of fresh-frozen herring Clupea harengus, mackerel Scomber scombrus and alewife Alosa pseudoharengus.

Coccidial infections were diagnosed by presence of oocysts in fresh faecal smears or flotations. In order to count oocysts, $1 \mathrm{~g}$ samples of faeces were suspended in saturated $\mathrm{NaCl}$ solution, samples from lightly infected seals being diluted to $10 \mathrm{ml}$ of suspension and those from seals with clinical symptoms to $100 \mathrm{ml}$. Ten $0.1 \mathrm{ml}$ subsamples of each suspension were pipetted in droplets onto microscope slides and oocysts therein counted under a dissecting microscope at 50x. Numbers of oocysts per gram faeces were then estimated from the total number counted in 10 subsamples of faecal suspension, $\times 10$ for samples from seals with subclinical infections, and $\times 100$ for samples from seals with clinical coccidiosis.
For sporulation rate determinations, fresh oocystladen diarrhea was collected from seals with clinical infections. Two ml samples of diarrhea were placed in $50 \times 15 \mathrm{~mm}$ Petri dishes with a thin layer of $2.5 \%$ potassium dichromate solution. Faecal samples were also placed in untreated Petri dishes and in $200 \mathrm{ml}$ jars of standing or aerated seawater. The samples were incubated at various temperatures from 0 to $35^{\circ} \mathrm{C}$ in water baths and temperature-controlled rooms with temperature being monitored twice daily. Oocysts were examined daily until sporoblasts had formed and at 4 to $6 \mathrm{~h}$ intervals thereafter. During each observation period the numbers of sporulated individuals in random samples of 200 oocysts were recorded. An expression developed by Bĕlehrádek (1935) was used to describe the sporulation time-temperature relationship.

Infected seals were treated with $1 \mathrm{~g}$ sulphadimide ['Sulfidine'; Ayerst Laboratories, Montreal PQ $10.5 \mathrm{~g}$ tablets)] twice daily for $5 \mathrm{~d}$ and chloramphenicol ['Chloromycetin'; Parke-Davis \& Co. Ltd, Brockville, Ontario (250 mg capsules)] twice daily for $15 \mathrm{~d}$. When treatment was used for subclinical infections or as a general control measure, the medication was implanted in herring and fed to the seals between regular meals. It was intubated with 10 to $20 \mathrm{ml}$ of homogenized herring to seals with clinical signs.

An 8 mo old male with clinical coccidiosis was euthanized by injection of 'Euthanyl' [MTC Pharmaceuticals, Hamilton, Ontario ( $2 \mathrm{cc} \mathrm{kg}^{-1}$ body weight)] into the intervertebral epidural vein when its condition continued to decline after receiving treatment for $24 \mathrm{~h}$. Tissue samples from the gastrointestinal tract were fixed in buffered $10 \%$ formalin, sectioned at 2 to $25 \mu \mathrm{m}$ and stained with haemotoxylin and eosin. Heidenheim's iron haemotoxylin or Brown \& Breen's stain (for Gram-positive and Gram-negative bacteria). Colonial meronts were counted by reconstruction of colonies from $25 \mu \mathrm{m}$ serial sections.

\section{RESULTS}

Oocysts, meronts and gamonts from captive Sable Island harbour seals Phoca vitulina were Eimeria phocae (Apicomplexa: Eimeriidae) (Hsu et al. 1974a).

\section{Exogenous stages}

Sporulation: Oocysts sporulated in thin layer cultures with potassium dichromate and also in untreated faeces. In thin layer cultures at 0.2 to $20^{\circ} \mathrm{C}, 85$ to $95 \%$ of the oocysts sporulated, mean sporulation time having a declining curvilinear relationship with temperature varying from ca $50 \mathrm{~h}$ at $20^{\circ} \mathrm{C}$ to $1300 \mathrm{~h}(54 \mathrm{~d})$ 


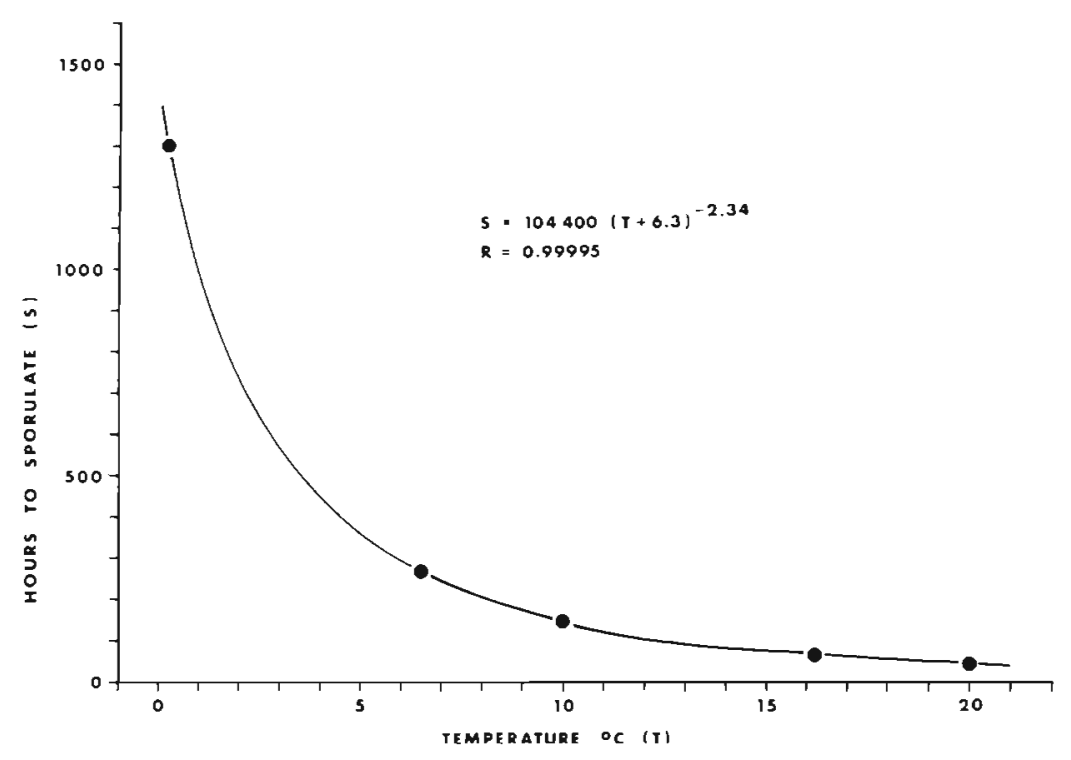

Fig. 1. Eimeria phocae oocysts from faeces of Phoca vitulina. Relationship of mean sporulation time $(\mathrm{h})$ to temperature $\left({ }^{\circ} \mathrm{C}\right)$

at $0.2^{\circ} \mathrm{C}$ (Fig. 1). At $25^{\circ} \mathrm{C},<10 \%$ of the oocysts sporulated and sporulation did not occur at temperatures $\geq 30^{\circ} \mathrm{C}$. When oocysts from faecal samples stored for $1 \mathrm{wk}$ at $-20^{\circ} \mathrm{C}$ were transferred to thin layer cultures at $20{ }^{\circ} \mathrm{C}$, ca $20 \%$ sporulated.

Maintenance in standing or aerated seawater inhibited sporulation but was not lethal to the oocysts. When unsporulated oocysts were transferred to $20^{\circ} \mathrm{C}$ thin layer cultures after $30 \mathrm{~d}$ in seawater at $20^{\circ} \mathrm{C}$, $>90 \%$ sporulated and the mean sporulation time was ca 50 h, i.e. the same as for oocysts introduced directly to thin layer culture.

Description (Figs. 2 \& 3): Unsporulated and sporulated oocysts ellipsoidal with yellowish-brown wall ca $3 \mu \mathrm{m}$ thick and micropyle ca $4 \mu \mathrm{m}$ in diameter. Sporulated oocysts $45.4(42$ to 47$) \times 23.6$ (22 to 25$) \mu \mathrm{m}(\mathrm{n}=100)$; length-width ratio $1.92(1.75$ to 2.04$)$. Sporulated oocysts contained 4 sporocysts, a single polar granule and 2 ovoid residua composed of coarse granules.

Sporocysts ovoid with a prominent Stieda body at the narrower end and large residuum of coarse granules. Sporocysts $18.0(15$ to 21$) \times 10.3(9$ to 12$) \mu \mathrm{m}(\mathrm{n}=100)$; length-width ratio 1.65 (1.36 to 2.11 ). Two bananashaped sporozoites, each containing small central nucleus and 2 refractile bodies, lay lengthwise head to tail in each sporocyst.

\section{Endogenous stages}

Prepatent period: Unknown.

Patent period: Seals P-9 and P-10 (see Table 1) with subclinical infections shed oocysts for 2 and $8 \mathrm{~d}$, re- spectively, and seal P-1, which exhibited clinical symptoms of coccidiosis, passed oocysts for $4 \mathrm{~d}$.

Location: Meront nodules and heavy concentrations of gamonts occurred in the proximal small intestine within 2 to $3 \mathrm{~m}$ of the pylorus but were rarely found together in histological sections. Gamonts were also found in lower densities throughout the small and large intestines.

Description (Figs. 4 to 8): Giant meronts occurred in colonies forming macroscopic nodules which extended from submucosa to intestinal lumen. Nodules were $1.28(0.90$ to 1.52$) \times 0.90$ (0.75 to 1.05$) \mathrm{mm}(\mathrm{n}=10)$ and contained 800 to 1200 meronts. Individual meronts ovoid to irregular with an emarginated host cell nucleus; all meronts in a given colony appeared to be at same stage of development. Developing meronts compartmentalized by invaginated cords of dividing nuclei while more mature meronts contained merozoites attached to walls or clustered on eosinophilic residua. Developing and mature meronts 100 (80 to 128$) \times 78$ (64 to 85$) \mu \mathrm{m}$ ( $n=100)$; merozoites were $6-8 \times 1-2 \mu \mathrm{m}(\mathrm{n}=100)$, broader towards anterior extremity with nucleus slightly anterior to mid-body.

Micro- and macrogamonts occurred in lamina propria of villi. Microgamonts were ovoid to irregular, with emarginated host cell nucleus. Immature microgamonts compartmentalized by invaginated cords of dividing nuclei and developing microgametes; mature specimens containing numerous biflagellate microgametes and amorphous eosinophilic residua. Developing microgamonts 74 (52 to 120$) \times 46(29$ to 60$) \mu \mathrm{m}$ $(n=50)$; mature specimens 119 (88 to 142$) \times 99(65$ to 128) $\mu \mathrm{m}(\mathrm{n}=50)$. Macrogamonts were ovoid to ellipsoidal, 32 (22 to 41$) \times 26(20$ to 33$) \mu m(n=50)$, with emarginated host cell nucleus.

\section{Symptoms and pathology}

A total of 12 coccidial infections and reinfections were detected in 8 harbour seals between October 1974 and April 1975 (Table 1). Symptoms (usually vomiting) were also observed in a number of other cases but infections were not confirmed by recovery of oocysts from faeces. Oocysts were at no time detected in the faeces of 2 grey seal pups which shared facilities with 7 harbour seals from February to June 1975, including the period of April 3 to 15 when subclinical 

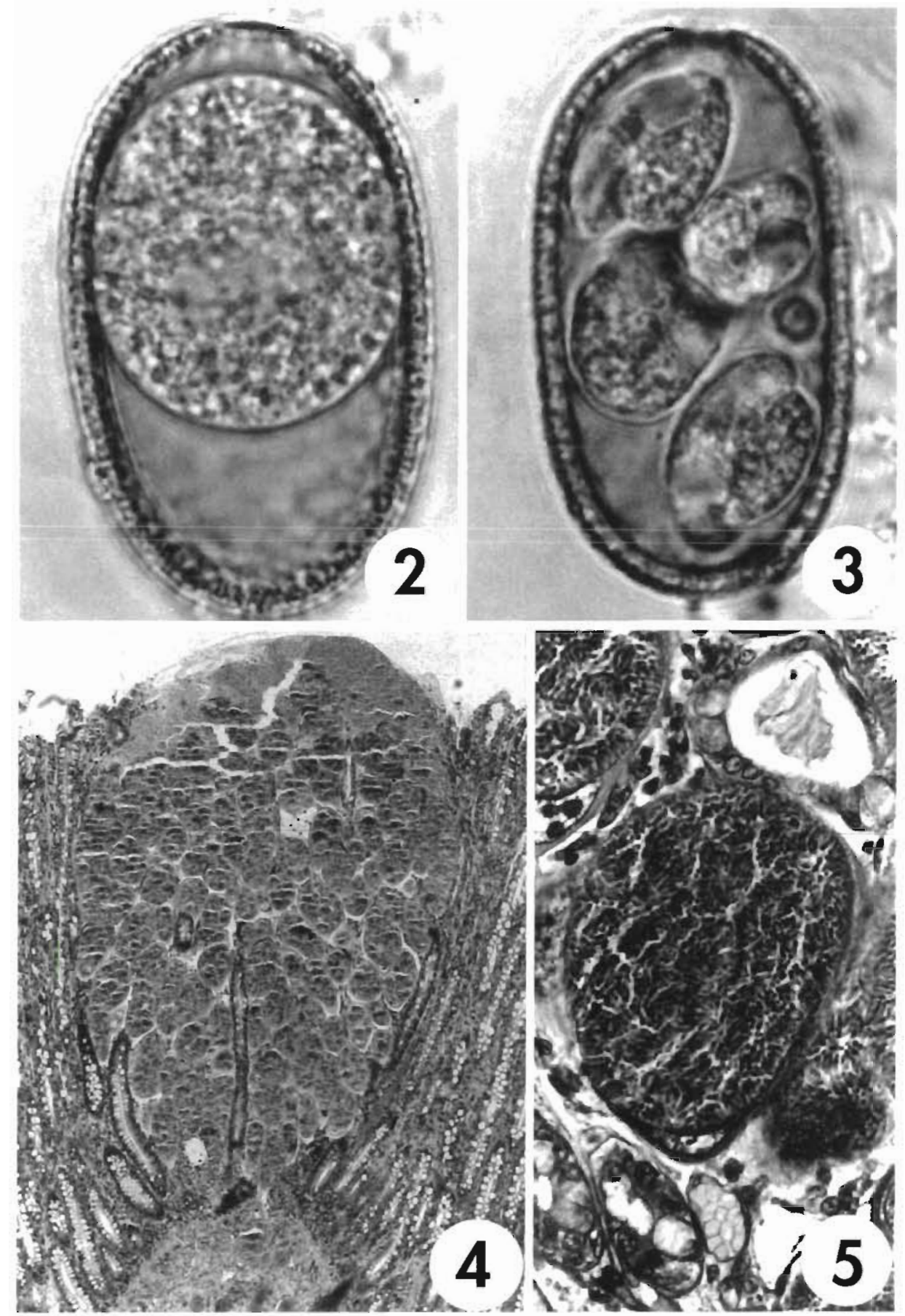

Figs. 2 to 5. Eimeria phocae infecting Phoca vitulina. Fig. 2. Fresh unsporulated oocyst from harbour seal faeces. $1900 \times$. Fig. 3. Fresh sporulated oocyst from thin layer culture of harbour seal faeces. Oocyst contains polar body near micropyle, 2 spherical residua (one partly obscured by a sporocyst) and 4 sporocysts, each containing 2 sporozoites. 1900x. Fig. 4. Section of proximal small intestine with meront colony in the mucosa. Haematoxylin and eosin, $65 \times$. Fig. 5. Mature meront with emarginated host cell nucleus in the lamina propria of proximal small intestine. Meront contains clusters of merozoites on eosinophilic residua. Haematoxylin and eosin, $500 x$
Eimeria phocae infections were diagnosed in each of the harbour seals.

Symptoms: Most infections were mild (occasional vomiting) or asymptomatic with oocyst sheds ranging from $<10$ to a few thousand $\mathrm{g}^{-1}$ faeces. Clinical signs including vomiting, lethargy, loss of appetite and haemorrhagic diarrhea containing hundreds of thousands of oocysts $\mathrm{g}^{-1}$ developed in 2 underweight $(<30 \mathrm{~kg}$ ) males, P-1 and P-8 (Table 1), housed in the outdoor tank.
Despite the occurrence of clinical symptoms, neither the October 1974 nor the February 1975 infections in P-1 were particularly severe. The seal remained alert and struggled vigorously when recaptured and isolated for treatment. During the fall incident, P-1 retired to the haulout area and fasted for 2 to $3 \mathrm{~d}$. With the onset of symptoms in winter, P-1 swam listlessly around the tank, initially ignoring food, but regaining his appetite a few hours later. On the other hand, P-8 was found floating in 

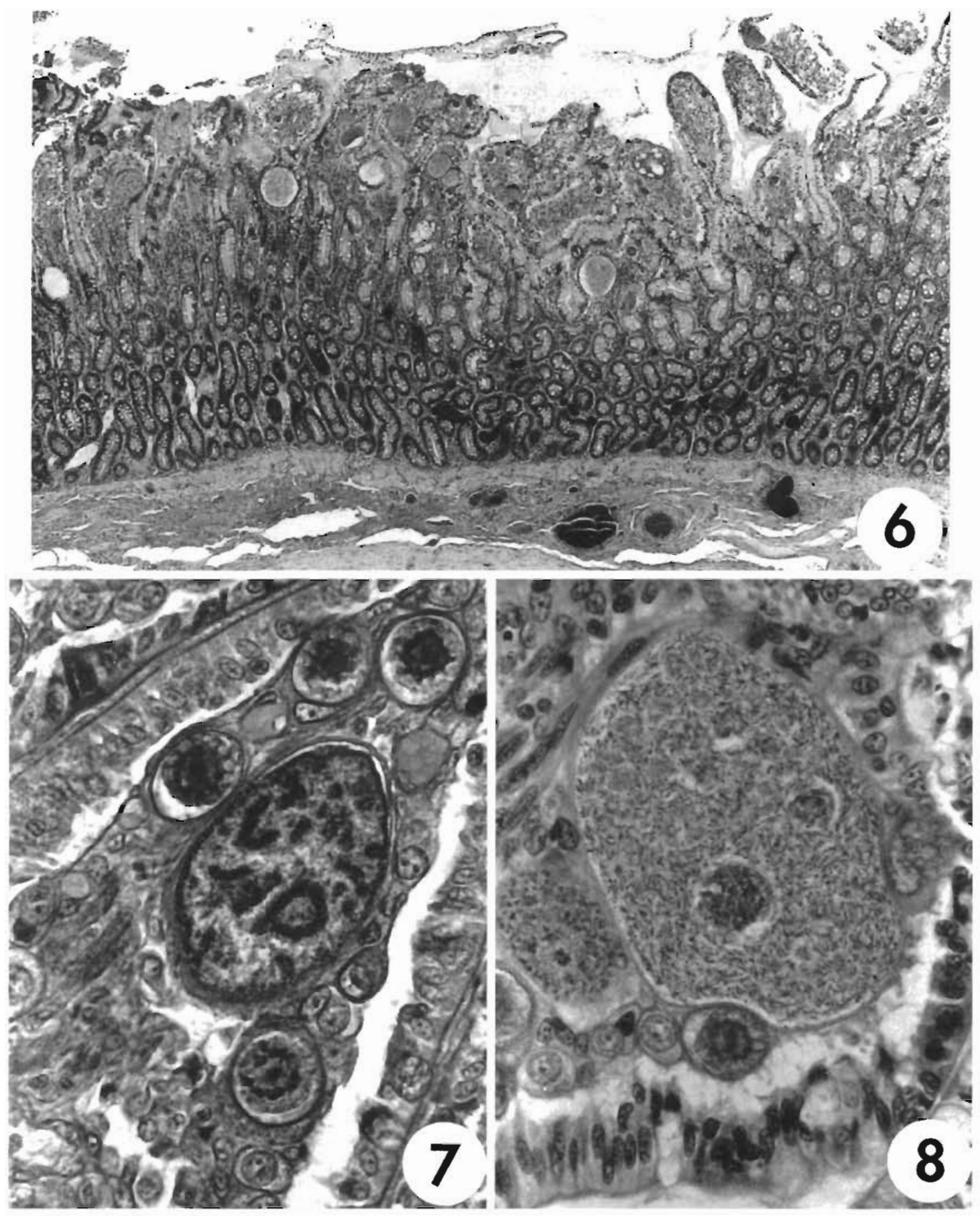

Figs. 6 to 8. Eimeria phocae gamonts in sections of the proximal small intestine of Phoca vitulina. Haematoxylin and eosin. Fig. 6 Section of haemorrhagic and necrotic area of small intestines showing sloughing of epithelium, shortening and thickening of villi and heavy concentrations of gamonts in the lamina propria. 50×. Fig. 7. Developing microgamont surrounded by developing and mature macrogamonts and oocysts in lamina propria of a villus. Microgamont contains invaginating cords of dividing nuclei $650 \times$. Fig. 8. Mature microgamont in lamina propria of villus. Microgamont contains numerous biflagellate microgametes and eosinophilic residua. $650 \times$

the tank, asleep, with head retracted into fleshy folds of the neck, foreflippers pressed to the body and hind flippers folded and cupped together. The animal was motion- less but for intermittent ex- and inhalations. After being isolated and treated for $24 \mathrm{~h}, \mathrm{P}-8$ appeared to be near death, offering no resistance when intubated medication. 
Table 1. Eimeria phocae infections in Sable Island harbour seals Phoca vitulina housed in the Life Sciences Centre, Dalhousie University, October 1974 to April 1975

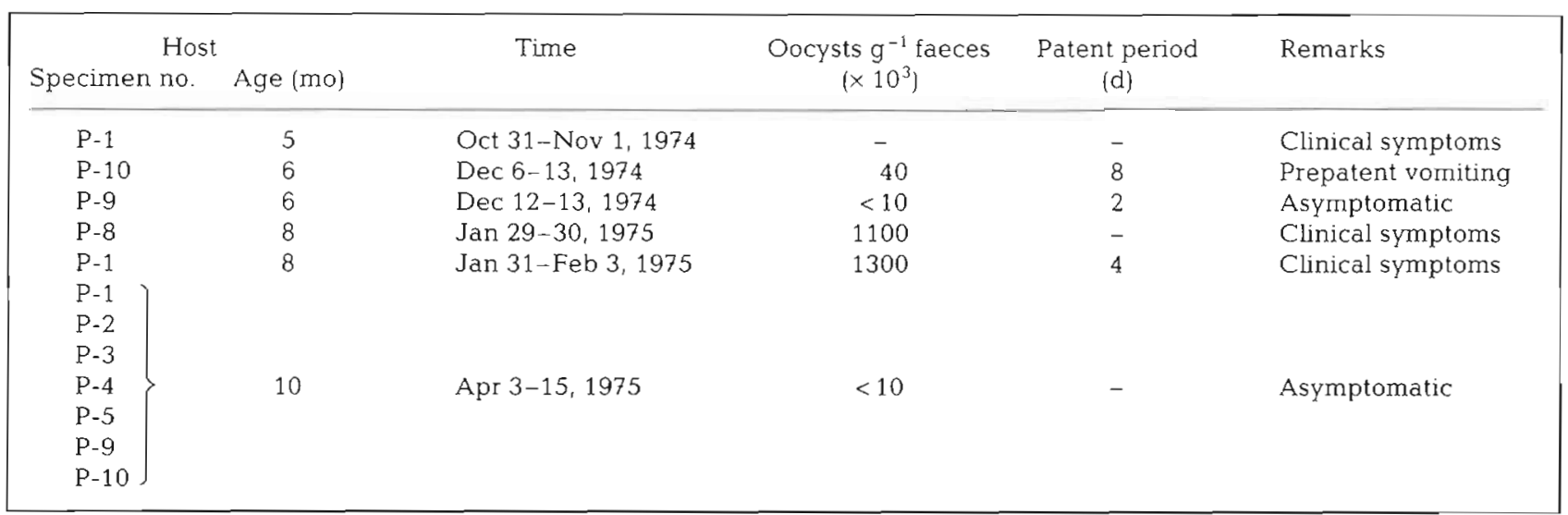

Pathology: At autopsy, P-8 exhibited complete vasoconstriction. Haemorrhagic fluid was found in the stomach and throughout the intestines but haemorrhaging was confined to the mucosa of the pylorus and proximal $3 \mathrm{~m}$ of small intestine. Widely scattered white nodules, which subsequently proved to be meront colonies, were also evident in the mucosa of the upper intestine.

Meront colonies produced displacement or compression necrosis of adjacent tissues, but the damage was localized and there was no inflammation (Fig. 4). Host tissues (lamina propria, epithelium, crypt glands and blood sinuses) were often incorporated within the colony. Areas of high gamont density (Figs. 6, 7 \& 8) were marked by haemorrhaging and polymorphonuclear leukocyte infiltration, particularly by eosinophils. There was shortening and thickening of villi and epithelium and lamina propria were necrotic and had sloughed off in some areas. There was no evidence of secondary bacterial infections.

\section{DISCUSSION}

Hsu et al. (1974a) observed that most oocysts of Eimeria phocae from Maine harbour seals sporulated after 42 to $52 \mathrm{~h}$ in thin layer culture at $26^{\circ} \mathrm{C}$. While optimal for sporulation of eimeriid oocysts from domesticated animals (Joyner 1982), temperatures of 25 to $30^{\circ} \mathrm{C}$ proved lethal for $E$. phocae oocysts from Sable Island seals in the present study, with $>90 \%$ of those incubated at $25^{\circ} \mathrm{C}$ and $100 \%$ of those held at $30^{\circ} \mathrm{C}$ failing to sporulate. However, at 0.2 to $20.0^{\circ} \mathrm{C}$, a temperature range more typical of the seal host's North Atlantic habitat, 85 to $95 \%$ of E. phocae oocysts sporulated. Mean sporulation time varied from 50 h at $20.0^{\circ} \mathrm{C}$ to $1300 \mathrm{~h}(54 \mathrm{~d})$ at $0.2^{\circ} \mathrm{C}$, sporulation time having a declining curvilinear relationship with temperature
(Fig. 1). The fact that some (ca $20 \%$ ) E. phocae oocysts sporulated after storage for $1 \mathrm{wk}$ at $-20^{\circ} \mathrm{C}$ indicates that they might also survive periods of extreme cold on natural seal haulouts in winter.

Investigators (Hsu et al. 1974b, Lauckner 1985, Munro \& Synge 1991) who advocate frequent replacement of water in holding tanks to prevent Eimeria phocae reinfections in captive seals seem to have assumed that the parasite sporulates and is transmitted in water. In the present study, however, infections occurred repeatedly in harbour seals held in a $40 \mathrm{~m}^{3}$ outdoor seal tank equipped with a flow-through system delivering fresh prefiltered seawater at a rate $\left(0.3 \mathrm{~m}^{3} \mathrm{~min}^{-1}\right)$ sufficient to replace its contents more than 10 times daily. As further revealed experimentally in this study, E. phocae oocysts sporulate in faeces incubated under moist air but not when suspended in standing or aerated seawater. Hence, oocysts probably sporulate on haulout areas. Given that transmission of E. phocae appears to be direct (Hsu et al. 1974a), it seems reasonable to conclude that free-living and captive seals on crowded haulouts may become infected by ingesting or inhaling sporulated oocysts from soiled pelage during grooming or nursing. Captive seals may also ingest oocysts with food which has been dragged across soiled haulouts.

It is unlikely that coccidia were transmitted in the outdoor seal tank at Dalhousie University during the winter. With air temperatures in the facility often falling below freezing December through March, sporulation of oocysts, if not completely arrested, would require several weeks (see Fig. 1). Moreover. after diagnosis of coccidia, the facility was cleaned frequently, with haulout areas being hosed off daily. It seems more likely that the parasite overwintered in the indoor pool tank, which was occupied by harbour seal pups involved in behavioral experiments between late summer 1974 and spring 1975 and which also served 
as temporary quarters for seals from the outdoor tank while repairs were made to the latter facility in early January 1975 . At 15 to $20^{\circ} \mathrm{C}$, the air temperature in the indoor tank was suitable for rapid sporulation of oocysts throughout the year.

The prepatent period of Eimeria phocae is thought to be 20 to $25 \mathrm{~d}$, the time elapsed between a fatal case of coccidiosis in a captive harbour seal at Johns Hopkins University and the onset of symptoms in a second harbour seal held in the same facility; patency was $11 \mathrm{~d}$ in the second animal (Hsu et al. 1974b, Howard et al. 1983, Lauckner 1985). Patent periods of coccidial infections in harbour seals held in the Life Sciences Centre in the present study varied from 2 to $8 \mathrm{~d}$ and, although the evidence for duration of the prepatency period is somewhat circumstantial, it may not be a coincidence that midwinter clinical infections in 2 undersized males became patent $23 \mathrm{~d}$ after each animal had been temporarily transferred to the indoor holding tank in early January 1975. As indicated above, midwinter transmission of the parasite in the outdoor tank seems unlikely and, thus, both animals may have been exposed to sporulated oocysts during a 4 to $5 \mathrm{~d}$ residency in the indoor facility. Notably, P-8, which had been transferred to the indoor tank $24 \mathrm{~h}$ before $\mathrm{P}-1$, also developed symptoms and began passing oocysts a day earlier than P-1 (Table 1).

Meronts of Eimeria phocae were observed for the first time in the present study. They were remarkable in 2 respects. First, they occurred in colonies of several hundred individuals which formed nodules visible to the naked eye in the mucosa of the upper intestine. Secondly, the meronts themselves were quite large $(80-128 \times 64-85 \mu \mathrm{m})$, rivaling the giant first-generation meronts of Eimeria spp. of bovids (see Levine 1982) in size. The fact that meronts described here occurred in large discrete colonies suggests that they were second-generation meronts and that each colony may have arisen from single first-generation meronts.

Eimeriid micro- and macrogamonts found in a harbour seal from Sable Island in this study closely resembled gamonts of Eimeria phocae described from a harbour seal captured near Portland, Maine (USA) (Hsu et al, 1974a). However, while gamonts occupied the lamina propria of intestinal mucosa in each case, heaviest concentrations (and associated pathology) occurred in the colon of the Maine harbour seal and in the proximal small intestine of the Sable Island seal. The difference in location of gamonts in the 2 seals is noteworthy, in view of the site specificity usually exhibited by endogenous stages of Eimeria spp. (Joyner 1982). As was the case in the present study, heavy concentrations of gamonts and associated pathology occurred in the small intestine of 2 common (harbour) seals which died of coccidiosis in a Scottish seal sanctuary (Munro \& Synge 1991).

As evident above, coccidia reported here differed from Eimeria phocae of Maine harbour seals not only in respect to site selection of gamonts but also in regard to the upper temperature tolerance levels of the oocysts. Such variation might be anticipated in coccidia from geographically isolated host populations. Sable Island lies at approximately the same latitude as Portland, Maine, but more than $600 \mathrm{~km}$ to the east, near the edge of the continental shelf. Harbour seals on the island seem to be an isolated population, distinct from mainland seals in pelage, cranial features and dentition (Boulva \& McLaren 1979). Recent markrecovery data (Wayne Stobo, Bedford Institute of Oceanography, Dartmouth, Nova Scotia, pers. comm.), however, reveal that while Sable Island harbour seals may not interbreed with other populations, some, particularly younger animals, have been found along the Nova Scotian and American coast as far south as New Jersey, where they would presumably interact with mainland seals

Coccidial infections may cause disease in captive seals predisposed by stress of capture and confinement, change of diet, handling, poor sanitation and overcrowding (Munro \& Synge 1991). Despite the pathogenicity of Eimeria phocae, seals in good physical condition can nevertheless survive an infection (Lauckner 1985). Each of the 16 juvenile seals housed in facilities at Dalhousie University from June 1974 to June 1975 may have been infected with $E$. phocae at least once, and the fact that clinical symptoms developed in only 2 seals is testimony to the good condition of the animals and the high quality of care which they received. Indeed, the animals which incurred clinical infections were the 2 smallest seals in the colony and the added stress of an unfortunate, but necessary, midwinter transfer from an outdoor to an indoor holding tank was clearly a contributing factor in 2 of the 3 clinical cases.

Harbour seals are thought to have a high natural mortality during their first year (Boulva \& McLaren 1979). Katona et al. (1983), for example, report a first year mortality rate of $30 \%$, attributable variously to abandonment, storms, disease, parasites and predation by sharks, although they do not identify the source of this estimate. Given their pathogenicity in confined seals (Hsu et al. 1974b, Munro \& Synge 1991, present study), coccidia are almost certainly implicated in disease and mortality of weak or undernourished juvenile seals in the wild. Predisposing factors in free-living seals might include abandonment, other parasitic infections or diseases and injuries which limit ability to forage. 
Acknowledgements. The author is grateful to Dr J A. Love, formerly of the Animal Care Centre, Dalhousie University, for recommending treatment and providing drugs and autopsy facilities, and to Dr Ian McLaren of the Biology Department, for suggesting the use of the Bèlehrádck expression to describe the sporulation time-temperature relationship. Gratitude is also extended to Gary Tanji, employed at the time in the Physiology Department, Dalhousie University, for assisting at the autopsy, and to John Martell of the Department of Fisheries and Oceans, Halifax, Nova Scotia, for assisting in the preparation of the manuscript. The work was supported by U.S. Department of Heath, Education and Welfare Contracts 223-75-2127 and 223-77-2128.

\section{LITERATURE CITED}

Bëlehrádek, J. (1935). Temperature and living matter. Protoplasma Monographia, No. 8. Borntraeger, Berlin

Boulva, J., McLaren, I. A. (1979). Biology of the harbour seal, Phoca vitulina, in eastern Canada. Bull. Fish. Res. Bd Can. 200: 1-24

Cowan, D. F. (1966). Pathology of the pilot whale Globicephala melaena. A comparative survey. Arch. Pathol. 82: $178-189$

Dailey, M. D. (1985). Diseases of Mammalia: Cetacea. In: Kinne, O. (ed.) Diseases of marine animals, Vol. IV, Pt. 2, Introduction, Reptilia, Aves, Mammalia. Biologische Anstalt Helgoland, Hamburg, p. 805-847

Dróżdż, J. (1987). Oocysts of six new Coccidiomorpha species from pinnipeds of King George Island (South Shetlands, Antarctic). Acta Protozool. 26: 263-266

Howard, E. B., Britt, J. O. Jr, Matsumoto, G. (1983). Parasitic diseases. In: Howard, E. B. (ed.) Pathobiology of marine mammal diseases, Vol. I. CRC Press, Boca Raton, p. $119-233$

Hsu, C. K., Melby, E. C., Altman, N. H. (1974a). Eimeria

Responsible Subject Editor: M. D. Dailey, Gunnison, Colorado, USA phocae sp. n. from the harbor seal (Phoca vitulina concolor). J. Parasitol 60: 399-402

Hsu, C. K., Melby, E. C., Altman, N. H., Burek, J. D. (1974b) Coccidiosis in harbor seals. J. Am. vet. med. Ass. 164 $700-702$

Joyner, L. P. (1982). Host and site specificity. In: Long, P. L (ed.) The biology of the Coccidia. Edward Arnold, London, p. $35-62$

Katona, S. K., Rough, V., Richardson, D. T. (1983). A field guide to the whales, porpoises and seals of the Gulf of Maine and Eastern Canada from Cape Cod to Newfoundland, 3rd edn. Charles Scribner's Sons, New York

Kennedy, M. J. (ed.), Margolis, L., Arai, H. P. (1989). Synopsis of the parasites of vertebrates of Canada - Parasites of marine mammals. Alberta Agriculture, Animal Health Division, Queen's Printers, Edmonton

Lainson, R., Raiff, R. D., Best, R. C., Shaw, J. J. (1983). Eimeria trichechi $\mathrm{n}$. sp. from the Amazonian manatee, Trichechus inunquis (Mammalia: Sirenia). Syst. Parasitol, 5: 287-289

Lauckner, G. (1985). Diseases of Mammalia: Pinnipedia. In Kinne, O. (ed.) Diseases of manne animals, Vol. IV, Pt. 2 , Introduction, Reptilia, Aves, Mammalia. Biologische Anstalt Helgoland, Hamburg, p. 683-793

Levine, N. D. (1982). Taxonomy and life cycles of coccidia. In Long, P. L. (ed.) The biology of the Coccidia. Edward Arnold, London, p. 1-33

McClelland, G. (1980a). Phocanema decipiens: molting in seals. Exp. Parasitol. 49: 128-136

McClelland, G. (1980b). Phocanema decipiens: pathology in seals. Exp. Parasitol 49: 405-419

Munro, R., Synge, B. (1991). Coccidiosis in seals. Vet. Rec 129: $179-180$

Upton, S. J., Odell, D. K., Bossart, G. D., Walsh, M. T. (1989) Description of the oocysts of two new species of Eimeria (Apicomplexa: Eimeriidae) from the Florida Manatee Trichechus manatus (Sirenia: Trichechidae). J. Protozool 36: $87-90$

Manuscript first received: April 6, 1993

Revised version accepted: June 14, 1993 